\title{
Zionist Detection through Indirection in Jonathan Wilson's A Palestine Affair
}

https://doi.org/10.33806/ijaes2000.19.2.7

\author{
Mahmoud Zidan \\ The University of Jordan, Jordan
}

\begin{abstract}
This paper explores Jonathan Wilson's A Palestine Affair (2003), reflecting on the parallels between its underlying logic on one hand and the illogic of liberal Zionism and the state of Israel on the other hand. The paper revolves around the rationalizing, detective apparatus deployed in the novel both thematically and formally. More specifically, it dwells on the ways in which the form of the novel buttresses its ideological underpinnings, or rather its content. I argue that the form selected by the writer; that is, the detective novel, mirrors the Zionist quest for colonizing Palestine, especially in the context of Jerusalem. I further suggest that by means of detection, Jerusalem is familiarized in the text so much so that readers might think of it as a new London, with the "here" of Britain expanded and its cultural incorporation into the Zionist imaginary facilitated. That familiarity obfuscates and negates the presence of Palestinians in Jerusalem and Palestine at large, who are mostly portrayed as marginal, inconsequential, and criminal characters. At the same time, the novel gives rise to an alternative creative, detective vision that does not necessarily entail the use of typical methods of detection, a vision that mirrors the Zionist conquest, especially in its so-called liberal form. Employing what I call counter-detection, I aim to excavate the problematic aspects of both detection and creative detection (detection through indirection) and show their complicity with the conquest of Palestine through paying close attention to the writer's Zionization of the artist on whose life the protagonist is modelled.
\end{abstract}

Keywords: A Palestine Affair, Detective fiction, counter-detection, mapping, Palestine, Zionism,

\section{Introduction}

Before laying out the argument, I would like to begin by adumbrating two premises or probably caveats that will be pivotal to its development. First, there is a tendency in literary studies and critical theory to jettison popular literature such as detective and crime fiction (what I mean by popular literature is that which appeals to people in general but not necessarily to most critics and theorists and thus does not receive wide treatment on the part of those theorists and critics). That jettisoning assumes the form of not engaging it critically or not sanctioning it pedagogically. That is why teaching detective fiction, gothic novels, or thrillers might sometimes be frowned upon by many a scholar. Hence, a distance between what scholars do and what readers normally read. More importantly, these critical and pedagogical tendencies further the distance between life and criticism by focusing on canonical works and putting aside some of the generative forces of culture and more broadly of lived realities. That is, it is my firm belief that any attempt at understanding culture that does not take cultural artifacts, the high and 
the low, into account is lacking. Indeed, a few critics (See, for instance, Terry Eagleton's Literary Theory: An Introduction(1996) and Pierre Bourdieu's study of taste in his book Distinction: A Social Critique of the Judgment of Taste (1984)) questioned the values that we employ to assign the labels 'high' and 'low.' The first premise then involves the definition of literature per se.

The second premise concerns another unfortunate underlying principle of current literary practices in some circles that are invested in the question of Palestine; that is, avoiding - like the plague - any serious investigation (the pun is intended) of popular literature produced by Zionists. One recent laudable exception was initiated by Amy Kaplan in her cogent article 'Zionism as anticolonialism: The case of Exodus' (2013). In it, Kaplan discusses the impact of Leon Uris's Exodus (1958), a popular Cold War novel and the movie into which the novel was made, on shaping ordinary Americans' attitudes towards the then newly established state of Israel. Kaplan forcefully shows that the novel, along with the film, helped, in the 1950s, disseminate the Israeli myth that Israel was an anticolonial force that was engaged in a war of resistance against the British, who were in turn aided and abetted by Palestinians. By shedding light on a novel that critics do not necessarily teach or pay attention to, Kaplan excavates its cultural purchase so that she can - in part-provide better understanding of the era, Zionism, and "American" culture, throwing into relief the provenance of the inextricable linkage between Zionism and the United States.

Having these two premises or assumptions in mind, I thus embark on an analysis of a novel that is not very well known by a writer who is not well known either, at least in academic circles. I focus on this novel, Jonathan Wilson's $A$ Palestine Affair (2003), to demonstrate the parallels between its underlying logic on one hand and the illogic of liberal Zionism and the state of Israel. My intervention revolves around the rationalizing, detective apparatus deployed in the novel both thematically and formally. More specifically, the paper dwells on the ways in which the form of the novel buttresses its ideological underpinnings, or rather its content. I argue that the form selected by the writer; that is, the detective novel, mirrors the Zionist quest for colonizing Palestine, especially in the context of Jerusalem. By means of detection, Jerusalem is familiarized in the text so much so that readers might think of it as a new London, and the "here" of Britain is expanded, facilitating the cultural incorporation of Jerusalem into the Zionist imaginary. That familiarity obfuscates and negates the presence of Palestinians in Jerusalem and Palestine at large, who are mostly portrayed as marginal, inconsequential, and criminal characters. At the same time, the novel gives rise to an alternative creative, detective vision that does not necessarily entail the use of typical methods of detection, a vision that mirrors the Zionist conquest, especially in its so-called liberal form. If we presume, along with John Scaggs (2005:1-2), that "there are certain parallels between detection and literary criticism. Both are attempts to make sense of the here and now by examining the there and then," then this paper is an example of counter-detection of the novel's detection that examines both the here/there and now/then binaries without reinscribing them. Employing what I call counter-detection, I aim to excavate the problematic 
aspects of both detection and creative detection (detection through indirection) and show their complicity with the conquest of Palestine through paying close attention to the writer's Zionization of the artist on whose life the protagonist is modelled.

Counter-detection is a way of reading that troubles and seeks to undermine both detection and detection through indirection. It primarily intends to expose the complicity of the two types with controlling subjected groups of people, Palestinians in this novel, through the power of the detective's gaze. That is, counter-detection, as a way of reading, is simultaneously an exposure and a writing back to imperial ways of seeing and reading. As part of my counterdetection, I first discuss the structure of crime fiction and its underlying logic briefly. I then move on to closely read that structure into the novel. Finally, I develop the argument that the novel embodies the Zionist quest and its creative aspects, as it digs up a chimeric past and imposes it on the contemporary realities of Jerusalem and Palestine, through which process the protagonist, an artist, becomes a liberal Zionized detective.

\subsection{Crime Fiction and Literary Theory and Criticism: The Question of Policing (Art)}

When asked about his opinion on a critic's description of A Palestine Affair (2003) as a form of detection, Jonathan Wilson, the writer, vehemently replied:

From my perspective I cannot imagine a worse description of my novel than 'A detective romance'. It distresses me considerably that any reviewer should regard it as such. I don't believe that it at all fits inside the generic forms of a detective novel. It's a novel, as one other reviewer noted, 'of politics, art, murder, sex and history (personal and global) set in the rough and tumble that was Palestine in 1924.' I like that!" (emphasis in original; personal communication)

My reading of the novel then goes against Wilson's conception of his own novel, as I, too, argue that the novel relies heavily on detection. But before I start to analyze specific aspects of Wilson's novel, I turn to a brief description of the subgenre of detective fiction. In his Poetics, Aristotle (2002:14) writes that "tragedy is the imitation of a complete and whole action having a proper magnitude... To be a whole is to have a beginning and a middle and an end." This linear, teleological definition of plot by Aristotle is easily applicable to the detective novel, and that is why many critics find that crime fiction, perhaps more than any other genre, easily lends itself to the elements of the Aristotelian plot. Indeed, many structuralist critics in fact turned to detective novels in order to exemplify their theories about the structure of plots. Tzvetan Todorov, for one, uses it to develop his terms the sujet/fabula elements of any plot. More pertinently, Todorov identifies two main parts of detective stories: "the first is the story of the crime, and the second is the story of its investigation" (Scaggs2005:2). 
The element that has attracted the most attention in this genre, however, is the ending. Critics have rightly observed that the reader of a detective novel knows the ending from the very beginning; that is, the crime will be solved, and we will eventually know the perpetrator. Accordingly, critics have called its structure "retardatory" (Segal2010:153-154) and "retrograde" (Scaggs2005:33). These two terms intimate that detective stories are in a sense determined by their endings and that writers construct their narratives in reverse. Eyal Segal (2010:154) thinks that closure is a more appropriate term than ending, as the ending of a detective novel does not only signify a point in time but also the stability of the social order and a sense of "finality" as opposed to openness in other narrative structures. The implication of this description is that the closure of detective fiction has political and social implications, a situation which should not be surprising, as this subgenre-Bran Nicol (2011:449) writes-is "a fundamentally conservative genre, which is symptomatic of the realist, scientific, positivist impulses of modernity." In 'Poe and the origins of detective fiction,' Stephen Rachman (2010) makes a pertinent connection between nation-states and the existence of detective fiction, suggesting that the proliferation of detective fiction indicates the stability of the political system as well as the forceful role of the police in a state. Invoking Benedict Anderson's Imagined Communities (2006), Rachman (2010:20) goes on to assert that the role of detective fictions (exemplified by Edgar Allan Poe's characterization of Dupin which I discuss below) complements that of the newspaper in imagining any community.

One of the most dangerous ramifications of this positivism and conservatism is the cultural erasure that accompanies the closure of the detective novel as a state apparatus (to use Althusser (2008)). The ending is already known to exist, but for it to be closed and resolved as it normally is, much negation of apparently jarring elements(other races, genders, nationalities, and so on) needs to take place. In other words, many others are left unimagined and erased (literally and metaphorically). Commenting on his novel Anil's Ghost, Michael Ondaatie (quoted in Weese 2015:302) suggests that his postcolonial (detective) fiction is a response to the Western idea that "there are always answers, always solutions," an idea which Western hegemonic powers use to subjugate and impose their own truth values on colonized others. Saree Makdisi (2010), the eighteenth century British literature critic, discusses this idea of erasure in a different-but germane to the focus of this paper, namely Jerusalem - context in his 'The architecture of erasure.' In this article, Makdisi (2010:535) writes, "When possible, then, the [segregation] wall [in Palestine] as the signifier of erasure is itself erased in turnas though there were some magic trick that could erase Palestinians from the landscape without the trace of that erasure being evident." This architecture of erasure, if applied to detective fiction, also "erase[s]...without leaving a trace" by virtue of its closure-oriented structure that submerges social and economic instabilities in society.

Another cultural ramification of that emphasis on closure is spatialization, particularly because of the forward movement that characterizes the subgenre. From an ontological point of view, William Spanos-employing Heidegger- 
suggests that this kind of spatialization of temporality is indicative of crime fiction:

[T] he rational or rather the positivistic structure of consciousness that views spatial and temporal phenomena in the world as 'problems' to be 'solved' - constitutes a self-deceptive effort to find objects for dread in order to domesticate - to at-home - the threatening realm of Nothingness, the not-at-home, into which Dasein is thrown (geworfen).(1972:34)

Spanos suggests that the detective novel naturalizes concrete social and political issues through negating and substituting comfort for them. Spanos (1972:35) goes on to explain that this comfort is derived from the assumption that "an acute 'eye,' private or otherwise, can [certainly] solve the crime with resounding finality by inferring causal relationships between clues which point to it (they are 'leads,' suggesting the primacy of rigid linear narrative sequence)." Readers then experience comfort vicariously: the comfort felt by the detective when the crime is solved is generalized to other aspects of life. As a result, readers are rewarded with what an Aristotelian plot promises them: catharsis; that is, relief because of the restoration of order (Spanos 1972:36). In A Palestine Affair, the catharsis which readers may feel when the crime is solved by way of the novel's detection through indirection and its other detective procedures is based on the discomfort of the Palestinian other.

This catharsis comes to fruition in a state of fantasy, to use Jacqueline Rose's (1996) term. Rose (1996:10) develops this term in the context of the Israeli and South African states. She argues, "[T] he modern state is a fantasy-if it relies on fantasy for an authority it can ultimately neither secure nor justify." Rose here registers the sense of anxiety that underpins this state formation. Indeed, the state of fantasy (a phrase that cannot be more fraught in this context) which is developed in A Palestine Affair is deeply tied to anxieties. The novel revolves around two manifestations of such anxieties: It is based on the investigation of the assassination of Jacob Israel de Haan, an Orthodox Jewish anti-Zionist who was assassinated by gung-ho Zionist gangs in 1924 (see Gibbels (2014) and Soetendorp (1971)) and the solution of the crime by protagonist-cum-artist Mark Bloomberg, who is modelled on David Bomberg, an anti-Zionist Jewish British artist. But the architecture of erasure to which I referred above serves to bury those anxieties through its detective apparatus. Here, I differ with Alex Stahler (2009:40) who - in the only article on the novel-maintains that Wilson's "explicit or implicit criticism of Israeli (colonial) aggression...appears to be the result and the continuation of British colonial hegemony." On the contrary, I suggest that Wilson's novel is deeply complicit with colonialism on its own indirectly detective terms. Let us now look at those terms which are brought about by what I would like to call detection through indirection, a process that entails using creative methods of detective work including a different way of seeing or knowing rather than formal ways of detection. 


\subsection{Detection through Indirection in A Palestine Affair: Mark Bloomberg as a Seer}

In "The Purloined Letter," Poe, who is generally referred to as one of the foundational figures in detective fiction, provides two methods of undertaking detective work: the first is mathematical and uses the most advanced and precise technologies, and the second is indirect and creative. While this short story or tale celebrates the latter, it makes fun of the former and its practitioners (the French police). Unlike the French police, Monsieur C. Auguste Dupin adopts an unusual method of detection that reads the mind of the criminal, involves a high level of risk, and uses imagination in order to find a stolen letter. The endgame of Dupin's work is that he finds the letter for which the police have been looking and returns it to the woman from whom it has been stolen. One can find both forms of detection in Wilson's novel: detection and detection through indirection, with the latter being the privileged method without necessarily resulting in a successful resolution, unlike in Poe's story. Rather than solving the crime using typical ways of detection, the detection through indirection of A Palestine Affair hinges on the detective's ability to gaze from a power-based position, willingness to take risks, and creative imagination.

Wilson's A Palestine Affair is set in 1924-Palestine, which was under the British mandate at the time. The novel specifically revolves around the experiences there of a British Jewish painter called Mark Bloomberg. During their stay there, Bloomberg and his wife Joyce are forced to encounter different early conceptualizations of Zionism. An assassination of an Orthodox Jew is played out in his backyard, a situation which places him in the middle of an investigation. While British investigators rush to the scene to identify the perpetrator of the crime, Bloomberg initially seems indifferent to it.

In contrast, the British Jewish detective, Robert Kirsch (based on a Zionist British Colonel in the name of Frederick Kisch), takes a deep interest in the case. At the beginning, he accuses Saud, a 16-year-old Palestinian boy, of having committed the murder despite having no evidence that gives any legitimacy to his accusation. When Kirsch first looks at the boy, he uses his power of induction and vision: "The boy couldn't have been more than sixteen. Kirsch wrote down his full name, Saud al-Sayyid; his address, on the Street of the Chain; and then his age, which Kirsch had guessed correctly" (Wilson 2003:48; subsequent citations of the novel will only include page numbers). After a short interrogation, Kirsch "let[s] the boy go...but...keep[s] him under observation" (49). The boy is then released and sent with Bloomberg, the painter, to Petra so that he can assist him in painting the ancient city. Now, Bloomberg becomes part of the detective work for the alleged crime, and his art, and the art of the novel itself, are transmuted into a rationalizing, detective apparatus for taking over Jerusalem, policing Jerusalemites, and coopting Palestinian land and culture.

At first sight, Bloomberg (who visited Palestine between 1923-1927 while it was under the British mandate) does not seem to be in the right place. $\mathrm{He}$ is disoriented by the new surroundings, being a recent arrival from the U.K., and he is - more importantly - traumatized by both the death of his brother and his WWI 
experience. He is even dissatisfied with the project that he is paid to do. Talking to his wife at the beginning of the novel, Bloomberg "produced his letter of instruction from his back pocket. 'A series of works depicting Life Under Reconstruction Conditions. Progress. Enterprise. Development.' In other words, inspiring representations of Jewish pioneers. In other words, propaganda" (5). Funded by the Palestine Foundation Fund, Bloomberg has to spend his time "sketching Jewish men and women at work" (59) to convince the world of the existence of the Israeli community, a task about which he is unenthusiastic and skeptical. What Bloomberg says shows his lack of interest in Zionist propaganda, and this is a precise rendering of the artist on whom Bloomberg is based, Bomberg. In The Memoirs of Sir Ronald Storrs (1937:446), Ronald Storrs (Ross in the novel), the military governor of Jerusalem at the time, writes that "Bomberg, though entirely Jewish, was not a Zionist." This description shows that Wilson's transmutation of Bomberg into Bloomberg is accurate (an accuracy which he will abandon towards the end of the novel).

True to the model, Wilson also creates a protagonist that is capable of rendering everything seeable, mappable, and detectable. The narrator tells readers, "Bloomberg looked beyond the terraces across the dip and swell of the earth toward Siloam and the Mount of Olives, then set up his easel and canvas. As always before painting he executed detailed sketches of his surroundings. He sat on a rock and worked in his pad with charcoal and pencil" (4). His gaze accordingly enables him to familiarize and reify the objects (be they human beings or flora and fauna)at which he looks. Whatever he wants to paint is at his own disposal: "The previous day Bloomberg had begun to set out the work in charcoal: the city spread out before him with the morning sun coming over the hills. He could do this kind of thing with his eyes closed - and perhaps would be better" (32). The idea that he can paint with his eyes closed suggests that the material realities are irrelevant. Further, one cannot ignore the verb "spread out" in connection with Jerusalem. To Bloomberg's mind, Jerusalem is rendered through significant metaphors: an object that can be studied (like a book) and an object of desire that can be feminized and 'enjoyed.' Here, Wilson closely follows the life of Bomberg in his characterization of Bloomberg. Critics have commented on Bomberg's growing visual awareness in his Palestine paintings in comparison with his pre-Palestine art works (See Capet (2010) for more on painting Palestine during the Mandate). For instance, Sarah MacDougall and Rachel Dickson (2017:104) note that Bomberg "was to experience in Jerusalem a dramatic awakening to the visual potential of landscape," and Richard Cork (1983:18) goes so far as to suggest that Bomberg "had learned how to look during the years of intense observation in Palestine." What is missing in these observations is the hierarchical power with which increased visibility provides Bomberg, a power that Storrs (1937:446) describes as Bomberg's "powerful cosmic stare."

Wilson's narrative-perhaps unwittingly-highlights this increased hierarchical visibility to a fault, as the examples above show. It is important then to stress that the narrative's metaphoric description is enabled by Bloomberg's gazing power which is based on his imagination, more precisely on previously 
received and perceived notions. This gazing power exemplifies what Edward Said calls the textual attitude, an attitude that makes him think that Amman for instance "was perhaps the size of a small London neighborhood" (91), his imagination being confined to what is familiar to him. This attitude should not be surprising, because Bloomberg takes part in "section mapping," as one of the British officers describes Bloomberg's work (87), a crucial method of control and conquest on the part of British imperialists. When his work is not recognized, Bloomberg regretfully says, "Hard to believe, you could die for your country if you were a Jew, but you couldn't map for it" (87).

More concretely, his art is coterminous with and analogous to the policies of the British empire in its imperial peripheries. It merits recalling that the British, and other colonizers for that matter, used to send many explorers in the $19^{\text {th }}$ and twentieth centuries to find archeological evidence that would justify the existence of Israel. Not to be confused with the Palestine Foundation Fund, which lay the foundations for Israel's colonial presence and to which Bomberg applied for funding (Cork 1983:7), the Palestine Exploration Fund is a case in point. T. E. Lawrence, or Lawrence of Arabia - as he is commonly called — was one of the first who benefited from the finances of the Palestine Exploration Fund (staying true to Benjamin Disraeli's dictum that "The East is a career" (quoted in Said 1978:epigraph) and took part in the mapping of the British imperial territories. In Measuring Jerusalem: The Palestine Exploration Fund and British Interests in the Holy Land, John James Moscrop (2000:4) elaborates on this mapping process: "The period 1912-14 saw the Fund used as a front for intelligence work. The Wilderness of Zin Survey, conducted by T. E. Lawrence and Charles L. Woolley, was nothing but a cover for the mapping work conducted by Captain Newcombe in the same area [Palestine]."'It is worth recalling that many Western travellers were obsessed with exploring Palestine at the time. "[T] hose who served there ultimately came to feel their own version of imperial nostalgia" (Sherman 2000:7). One British official writes, "At school, I probably knew far more about the geography of Palestine than of my own country" (Sherman 2000:16).) Mapping was thus an indispensable tool employed by British imperialism, and in the novel Bloomberg is shown as actively contributing to its deployment. (For more on mapping in (post)colonial contexts, see Anne McClintock's Imperial Leather (1995) and Mary Louise Pratt's Imperial Eyes: Travel Writing and Transculturation (2008).

The Governor of Jerusalem, Ross, is the organizer, sponsor, and incarnation of that deployment, and it is no wonder that the paths of the two cross. Not only does Ross sketch, but he is also obsessed with mapping and pictures: "On the wall behind Ross's desk was a photograph of Allenby entering Jerusalem, a map of the city, and a series of wood-framed, poorly-executed pencil sketches. Bloomberg recognized the Dome of the Rock and the Church of All Nations at the foot of the Garden of Gethsemane" (12).For Ross, maps are an excellent method of control. We are told, "The governor stood beside the car, resplendent in his white uniform. He was deep in conversation with a tall, fair-haired, well-dressed young man... The two of them were poring over a map that was spread out on the car's bonnet" 
(66). The words "spread out," "poring over," and "maps" replicate the textual attitude and its enabler, the power of vision, to which I have referred earlier. Indeed, maps accompany Ross everywhere, attendant with his fascination with architecture. When he first meets Bloomberg, Ross "spent half an hour describing his latest architectural project" (26). His choice of the studio in his house to be used by Bloomberg as an atelier suggests as much: "the roof of my house, there's a covered, shaded area, altogether a large area. Ideal, really. View of the whole city. Stunning" (24). One cannot help but notice Ross's awareness of the place of the city and the significance of his gaze that structures and constructs even as it destroys architecture in a way which is reminiscent of Makdisi's term "architecture of erasure."

Despite that allure, all of this visual control initially does not seem to attract Bloomberg in the least. It also fails to arouse his curiosity to know more about the assassination that takes place in his backyard, the assassination of Jacob Israel de Haan. In fact, Bloomberg is standoffish, and he only does what he is told to do. On the other hand, his foil, Kirsch presides over the investigation, and he does not hesitate to deploy his power of vision in his investigation to identify the criminal. Indeed, Kirsch comes prepared with all the detective paraphernalia, complete with a notebook, a pencil, and questions for multiple people, including Joyce, Bloomberg's wife (19). But the problem is that his are traditional methods of investigation, and he can only go so far. In spite of Kirsch's methodical or mathematical approach to the investigation, Bloomberg thinks that Kirsch might not be the right person for the job because of his Jewish ethnicity. He tells his wife Joyce, "Jews make terrible policemen...Too cocky. Too much imagination" (46). While Bloomberg sees "too much imagination" as being detrimental to the detective work in question, it is Bloomberg who will ironically resort to it and pay for its use - as he himself predicts. To illustrate, while Kirsch uses traditional methods of detection and eventually fails, Bloomberg deploys detection through indirection which affords him a sense of purpose and is predicated on the power of the gaze, the readiness to take considerable risks, and "too much imagination."

The inspiration for the excessive use of imagination comes from a coloniallinked endeavor, or rather adventure on which Bloomberg embarks. Ross sends Bloomberg to Petra, so that Bloomberg can paint "The Lost Temples of Petra," a place of whose existence Bloomberg is not aware (59). The trip is an important stage for Bloomberg, as it serves as a badly needed hiatus from his problems with his wife who he discovers is cheating on him with Kirsch, the detective. But because the trip is funded by the governor, it also comes with a condition: Bloomberg is assigned an assistant: Saud, the suspect Palestinian boy. From that moment onwards, Bloomberg's interest in the crime is heightened. For Bloomberg's imagination to be stoked even further and to color his mission with Englishness before Ross bids Bloomberg farewell, Ross reminds Bloomberg of John Burgon's poem about Petra, especially the two lines that English Literature professors generally employ to discuss hyperbole: "match me such marvel save in Eastern clime,/a rose-red city half as old as time" (84). 
Now, Bloomberg enjoys a critical distance from his suffocating surroundings, is enveloped in a mysterious, risky mission, and is brimming with creativity, all of which factors make him suitable for his primary task: detection through indirection. Saud makes that task much easier, particularly because he functions as the clue to the solution of the crime, and he is nothing but a clue, an instrument. His portrayal is telling. After all, he is a wooden character. For instance, after the death of Officer Cartwright, Saud does not react despite the dripping blood on his body from the dead man's: "The hole above Cartwright's ear leaked thick dark blood down Saud's thighs and legs and onto the floor of the car" (77). Saud does not even cry, scream, or express an emotion; he is merely a sidekick. For Bloomberg, Saud may be an asset, but his help becomes greater when Bloomberg realizes that he can achieve his potential through knowing who the criminal is.

The expedition itself, as it were, and Saud's assistance accordingly represent a watershed in the narrative in general and in Bloomberg's life in particular. This expedition plays a pivotal role in steering the course of events so that the text can now combine a quest narrative, a journey of self-discovery, and a mission that involves resolving the mystery of the crime. These three tasks become clearer when Rachman, his companion, "left Bloomberg alone to examine the landscape" (105). That examination, which reanimates Bloomberg's visual faculties (read gaze), leads him to the conclusion that he is after something that is much more profound than painting portraits or landscapes. For example, he is unable to paint a woman that he sees out of the window near the place in which he stays on the way to Petra; she becomes unpaintable: "He was after something deeper now and sought less and less of the world" (92). This deepening of purpose is obviously accompanied by a form of selective visuality that renders the Palestinian or Jordanian other nonexistent. From that moment on begins an arduous, winding journey: "the drivers negotiated the long serpentine curves that led, far too suggestively, Bloomberg thought, to the lowest point on Earth" (87), wherein Bloomberg becomes a seer par excellence. I would like to suggest that those serpentine roads are indicative of his method of detection through indirection, which is reminiscent of Monsieur Dupin's investigative approach in Poe's "The Purloined Letter" and whose manifestations into which I would like to delve now.

\subsection{Initial investigation}

The method of investigation that Bloomberg uses in his detection is similar to that of detective Dupin, who gives full rein to the imagination as opposed to mathematicality, including his looking for the solution to a crime in the most obvious of places. Bloomberg's method of detection through indirection first manifests itself in his ability to see through Saud (this seeing through is significant in the narrative if we recall that the boy is well-known in Jerusalem for his "homosexual" relationship with the victim of the assassination). When he first meets the boy, Bloomberg does not understand him very well: Saud earlier tells him that he has been lost in Jerusalem, which Bloomberg doubts, as the boy's 
responses seem to be automatic (106). Bloomberg is still unable to plumb the depths of Saud's situation: "Bloomberg sensed an urgency in the boy's response but had no key to understanding it" (107).

Bloomberg continues to observe, reflect, and detect until the boy-like the landscape - becomes an open book to him. Bloomberg is transformed into a lie detector, being capable of getting to the bottom of the truth. While painting Petra, he starts to use this capability(which is sharpened by his artistic activity), immersing himself into this self-proclaimed mission of identifying the criminal. His method of discovery, however, is not systematic yet systemic. It has no stages, but the result is already known, and the painting itself replicates it: "Was he finished with the painting? He thought he was done awhile ago, but in the mornings the painting seemed to be laughing at him for imagining the end. When would it be over? There was no plan, there were no stages" (153). The lack of stages or plan does not imply the dissolution of the power of vision; on the contrary, it creates more unpredictable spaces for that power to be exercised.

One can see Bloomberg's serious reflection on the matter in evidence in a letter that he composes to send to his wife, Joyce, a Zionist sympathizer. The narrator tells us that the conclusion of the letter is:

I may have found your Saud. But if so he doesn't seem like much of a murderer. I'll ask him tomorrow if he's ever stabbed anyone! [an expectation that he ridicules on the same page] Perhaps you'd better pass this onto the investigating officer...Or on second thoughts, maybe not. I wouldn't want him down here interrupting my work. (108)

The ambiguous phrase, my work, refers both to the painting and to his new line of work: detection through indirection. The fact that Saud is not likely to be the criminal (notice the use of the words "if," "may," "'ll," "perhaps," "maybe," "wouldn't," all of which show probability as opposed to certainty, exemplifying his experimentation with this new task) is the first fruit of his detective labor. In the same letter, which he, incidentally, does not send, Bloomberg further goes on to describe his detective thinking:

If Ross had sent this boy along to Petra he couldn't have suspected him of murdering De Groot. And then there was the boy's recent late-night visit to Bloomberg's house: why on earth, unless he'd spent a childhood reading English mystery novels, would a hunted murderer return to the scene of the crime? There had to be another explanation. Perhaps this Saud didn't even know De Groot. (108)

Apart from alluding to the subgenre of detective novels, Bloomberg makes careful inductions about the crime. Immediately after Bloomberg finishes composing these reflections, the narrator tells us, "Under these wild stars Bloomberg felt, for the first time in years, that he was exactly where he wanted to be" (108). This is a defining moment for Bloomberg. Now, he knows what his mission is about; he is certain about his sense of purpose. Being equipped with the ability to write letters (literacy) and imagination (visual ability and art), Bloomberg is ready and willing to solve the crime. 
The unsent letter, with which Bloomberg begins to investigate the crime, accrues more significance once we know that the crime is to be revealed by means of locating another unsent letter which De Groot has wanted to send to the Colonial Office in London, condemning Zionist militarization in Palestine. Bloomberg is convinced that locating this letter will help solve the crime, but he does not trace the letter until he confronts the boy. (Both of these letters recall Poe's purloined letter.) Bloomberg asks the boy directly and ludicrously, "Did you stab De Groot? Was it you?" The boy answers, “No, I didn't kill Yaakov. But I saw who did" (122).Saud then takes out a button that has fallen off the murderer's shirt and hands it over to Bloomberg, who in turn wraps it in "a torn piece of canvass."

While facing the beauty of Petra, Bloomberg thinks about what Saud has said to him. It is worth quoting from this scene at some length:

Bloomberg had come across colored sandstone before-it wasn't as if Britain didn't have any - but he had never seen colors of such depth and variety of pattern. The walls of rock reminded him of Eastern carpets, or some fanciful woven fabric. The deepest reds, purples, and shades of yellow were arranged in alternate bands, shading off into each other, and sometimes curved and twisted into astonishing fantasies. And he might have been overwhelmed, with awe and apprehension, except that his mind was elsewhere, anchored on the secret that Saud had revealed to him. (123)

The intersection of his power of vision and observation (detection) and his British-based Orientalistic imagination (indirection) enables Bloomberg to anchor himself. Moreover, it helps him to get closer to the perpetrator of the crime, the solution of which would provide him with even more colonial anchorage.

During this process, both Ross and Kirsch are sublated to Bloomberg's imagination. Preoccupied with the matter on hand, Bloomberg does not even respond to Ross's letters. He does not ask for protection either, despite being attacked on the way to Petra. All he is thinking about at this point is the safety of the boy (145). This fixation on solving the crime and saving the boy does not prevent him from continuing to work on his artwork. On the contrary, it fuels his art and motivates him to maintain a strategic distance from his object: "At first, Bloomberg worked far away from the rock face [of Petra]; the distance was necessary in order to secure the 'accurate views' that Ross desired" (145). It is clear that Bloomberg here grows more emphatic because of the return of the power of the gaze and its increasing scope.

Being thus empowered, Bloomberg cannot be thwarted from following his purposefulness to its conclusion: "I must go back to Jerusalem. The painting's finished. I have to deliver it" (154). In the meantime, he makes arrangements to protect Saud by sending him with Kirsch's cousins (whom he coincidentally runs into in Petra) to Cairo (which was under British dominion at the time). Bloomberg's philanthropy is not innocuous; it is underpinned by and complicit with the discourse of modernity, a discourse that distinguishes between the Arab "anti-modern" who needs help and the Western "modern" who can provide that 
help. The novel makes this distinction obvious. For instance, after Kirsch has an accident in Jerusalem, the narrator comments: "victims of the clash between modernity and its enemies - was it the motorbike or the cart that had done the damage?" (173). Indeed, it is an attitude that started much earlier in many texts written about the Holy Land such as Mark Twain's The Innocents Abroad and Herman Melville's Clarel. A. J. Sherman, one of the sources of Wilson's book, claims that Palestine was "inhabited by peoples not yet able to stand by themselves under the conditions of the modern world" (2000:11). (Sherman (2000:71) even associates Palestine with irrationality.) This illogic of the novel, from Sherman to Wilson to the West, rationalizes the colonization of Palestine.

Espousing this discourse, Bloomberg can only see himself as the helper and Saud as the helpee, as it were. When Saud pleads with him not to pursue his plan by saying, "The Zionists murdered Yaakov, they will do the same to me, and if you interfere, they will kill you too" (154), he does not budge and is determined to go back to Jerusalem. Unlike at the beginning of the novel, Bloomberg thinks, has a purpose, plans, and is ready to act: "Now he too was a man on a mission. Bloomberg patted his shirt pocket. The button was still there, wrapped in a torn square of canvas" (180). This image crystalizes his method of indirection: using art to find the "truth," to confirm his alternative method of detection through indirection; art making and sleuthing come together, with the canvas being metonymous of art. Despite this method's espousal of the discourse of modernity, it is still voiced by an anti-Zionist Jew (a vision that interestingly enough emulates that of many anti-Semites (See Joseph Massad's 'Zionism, anti-Semitism, and colonialism'). But the novel will turn the underlying logic of this method on its head through a narrative twist towards the end.

\subsection{The Closure}

The narrative twist that engenders a shift in Bloomberg's characterization comes after a crucial part of his detective work. The scene that best exemplifies Bloomberg's method of investigation and detection through indirection is the one that centers on Bloomberg's attempt to find Saud's family's house so that he can trace and locate the letter that exonerates Saud and incriminates the Zionists. From the very beginning of the scene, in which Bloomberg is looking for the whereabouts of the house of Saud's family, the mission seems to be both daunting and challenging because of the many risks that it involves. Bloomberg's movement is described as unwieldy - "he stumbled and swayed" (184) - and his entrance as "blind." He has to pass through a bazaar, a typically Oriental setting. The "blinds" of the windows of the stalls reinforce this metaphorical blindness, deadend-ness, and indirection. Those partly closed shutters further invoke the "seductiveness" of the East: "like seductively lifted skirts," with the wares on display being representative of the exoticism of the east: "a rug, or goldembroidered kerchief, or apricot papers" (184).

Saud's directions to his own family's place seem to be futile in this kind of deterministic environment: "Saud had given Bloomberg directions to his mother's home, but finding the place was another story"(184). The reason for that futility is 
what the narrator calls "the obligatory derangement" of the experience. This derangement should not be understood as negative and diverting. On the contrary, like his early unplanned painting of Petra, it might provide one with a goal, a destination:

The suq, once entered, demanded that you got lost, and for most of its visitors the obligatory derangement was a happy state: pilgrim, tourist or local shopper, the warren of alleyways would lead you eventually to the place that you sought, even if, at the outset of your journey, you were hardly aware that you had a destination in mind. (184)

This state of lostness does not mean that Bloomberg would not end up at a destination. In fact, the objects themselves seem to assist him in finding his way. When Joyce first arrives in the Old City and sees the bazaar she explains that mystery to Bloomberg, who is reluctant to accept it. She claims that "its objectsa rug, or gold-embroidered kerchief, or apricot papers - searched you out, rather than the other way round" (184). Through anthropomorphizing the objects, the "truth" becomes easier to access, and the way seems to be much clearer. The narrator tells us, "Eventually Bloomberg arrived near the Street of Chains without at all knowing how he had got there. Here the market was enclosed and its pink domed ceiling vaulted to a narrow opening that allowed light to fall in a bright shaft, as in an Old Master's renditions of celestial beams descending" (184). The lack of consciousness on the part of Bloomberg leads him to find the way. It was a stroke of luck, or rather a stroke of inspiration. The light suggests an epiphanic moment, a moment of revelation.

Once Bloomberg reaches the house, his eyes become piercing and penetrating into Saud's family's home, despite the early blindness that one notices at the beginning of the scene (which one can parallel with his ability to paint Jerusalem with his eyes closed). He seems to have shed this blindness and transferred it to Saud's brother: "A skinny boy, no more than nine or ten, came to answer; his eyes were clouded by trachoma and there were little scars on the surface of his lids. Bloomberg peered past him into the home. He was about to ask for Saud's mother but the boy reached out and took him by the arm" (184-185). This act of encroaching on the private space of the family is emblematic of the act of the detective, and the narrative renders that space penetrable and knowable. What is remarkable here is that despite the disorder that the protagonist faces, or maybe because of it, given his unconventional approach, Bloomberg restores order to the place. In a nutshell, this scene is representative of the entire method of the sleuth.

After he returns home, he peruses his finds (his archaeological excavation), a stack that Saud's mother Leila gives to Bloomberg. In a Dutch poetry book, Bloomberg accidentally finds "a folded piece of paper" (187), a copy of the letter that De Groot has wanted to send to the Colonial Office in London. De Groot's letter bears witness to the sensitive knowledge, to which Bloomberg is now privy too, that Zionists have been stashing and using weaponry in Palestine. De Groot makes it clear that he is worried about his own safety and wants to leave for London. Since he does not trust the local authorities of the mandate, he contacts 
the Colonial Office in London. In the letter, which must "have been intercepted," De Groot warns against "guns arriving through the port of Haifa" (206). This letter as a result proves Saud's innocence. What is striking about this letter is that Bloomberg, the sleuth-cum-artist, does not divulge all the contents to readers and only provides us with fragments. This unsigned letter then gestures towards the paradigmatic purloined letter, the one written by Poe, whose contents neither Poe nor his detective shares. The letter is thus full of erasure, which in turn produces Bloomberg as a knowing subject. (It is worth adding that Bomberg's Palestine paintings are figureless desert images (Cork 1987:149). The important question is: What is Bloomberg going to do with his knowledge, which incriminates the Zionists?

When Bloomberg is in Jerusalem, he tries to locate detective Kirsch, using the help of his wife, but his wife is arrested because of her collaboration with Zionist militarization. Equipped with the letter and his painting of Petra, he has to go to Cyprus, Greece to locate Governor Ross and divulge his knowledge. During this search for the governor, he is struggling with whether to defend his wife or not. The novel provides us with access to his thoughts: "[N]ow Joyce occupied all his thoughts; the image of her face glowed like an icon [he is in front of a Greek cathedral]. Her hopeful American face and lively gray-green eyes. The very picture of a Zionist terrorist. Life was mad" (240). Nevertheless, his knowledge of his wife's criminality leads him to the following moments-before-death decision, a sentimental narrative twist: "He knew exactly what he had to do here: bargain his silence for Joyce's release. De Groot's murderers would go free, but so would Joyce" (241). Wilson's decision to transform Bloomberg from an anti-Zionist Jew into a person who is ready to defend Zionism, even when he knows its terroristic tendencies, turns him into a liberal Zionist, a Zionist who embodies the values of Western democracies and sees the crimes of his country as exceptions to its liberal basis (For more on liberal Zionism and its connection with the US., see HonigParness 5 and Laor 8-9; see Steven Salaita for connecting Palestinians with Native Americans (24-25). This transformation, I suggest through my counter detection, points to the novel's investment in retrieving a tradition of liberal Zionism. The novel, as such, stages an extreme form of Zionism and liberates another, liberal Zionism, an apparently less militarized version that simultaneously infantilizes and thus erases Palestinians. This form of Zionism claims to know and indirectly controls Palestinians. This narrative is then intended as a rescue mission for Zionism by erasing its violent past.

But this rescue mission is not entirely successful. The button in the "torn square of canvass," one of the clues, embodies the notion that the method of indirection does not succeed because it is not recognized. Once recognized, this method of detection through indirection would guarantee the rejuvenation of Israel's state of fantasy, a fantasy that situates the state of Israel within the Western liberal democratic tradition. Jonathan Wilson's words here provide an insight:

I believe that the idea [behind writing the novel] began to germinate not long after the assassination of Yitzhak Rabin by a right wing 
Israeli extremist opposed to the peace process in November 1994. At the time there was a lot of soul searching among Jews not only in Israel but also worldwide and I frequently heard people express the idea that something new and unique had occurred (new and uniquely horrible of course): that new thing was believed to be one Jewish person politically assassinating another. Of course history had a different story to tell and I was aware of one case for sure, and one other most likely, where this had already happened. I ended up fictionalizing the 1924 murder of Jacob De Haan in A Palestine Affair (personal communication).

The writer seems to imply that for policing, or detection, to bear fruit, it has to be done through insidious indirection. One example would be the revival of an older Liberal Zionist approach, a European-based one. Where does the Palestinian fit into this narrative? Counter-detection tells us that Saud, the Palestinian, is a boy, who needs to be taken care of by Westerners, as the ending of the novel suggests: taken care of by Kirsch's cousins, which is a clear sign of patronage. Thus, Zionists continue to be the detectives, and the Palestinians the detected. It is this subtle, nuanced policing that the novel, I argue, advocates. Instead of the button being wrapped in a torn square of canvass, the novel provides a well-woven fabric of orderliness, but only for Israelis or/and liberal Zionists. Such nuanced artistic policing deserves further attention and generates more possibilities for resisting Zionist violence.

Mahmoud Zidan

Department of English Language and Literature

University of Jordan

Jordan

mh.zaidan@yahoo.com 


\section{References}

Althusser, Louis. (2008). On Ideology. London: Verso.

Anderson, Benedict. (2006). Imagined Communities: Reflections on the Origin and Spread of Nationalism. London: Verso.

Aristotle. (2002). The Poetics. South Bend, Ind.: St. Augustine's Press.

Bourdieu, Pierre. (1984). Distinction: A Social Critique of the Judgment of Taste. Cambridge, Mass.: Harvard University Press.

Capet, Antoine. (2010). 'Views of Palestine in British art in wartime and peacetime, 1914-1948'.In Rory Miller (ed.), Britain, Palestine and Empire: The Mandate Years, 85-100. Farnham, Surrey: Ashgate.

Cork, Richard. (1983). 'Bomberg in Palestine: The years of transition'. In Stephanie Rachum (ed.), David Bomberg in Palestine 1923-1927, 5-19. Jerusalem: The Israel Museum Jerusalem.

Cork, Richard. (1987). David Bomberg. New Haven, Connecticut: Yale University Press.

Eagleton, Terry. (1996). Literary Theory: An Introduction. Minneapolis, Mn: University of Minnesota Press.

Gibbels, Ludy. (2014). 'Jacob Israel de Haan in Mandate Palestine: Was the victim of the first Zionist political assassination a "Jewish Lawrence of Arabia"?' Jewish Historical Studies, 46 (1): 107-129.

Honig-Parnass, Tikva. (2011). False Prophets of Peace: Liberal Zionism and the Struggle for Palestine. Chicago, Illinois: Haymarket Books.

Kaplan, Amy. (2013). 'Zionism as anticolonialism: The case of Exodus'. American Literary History, 25 (4): 870-895.

Laor. Yitzhak. (2009). The Myths of Liberal Zionism. London: Verso.

MacDougall, Sarah and Rachel Dickson. (2017). Bomberg. London: Ben Uri Gallery and Museum.

Makdisi, Saree. (2010). 'The architecture of erasure'. Critical Inquiry, 36 (3): 519-559.

Massad, Joseph. (2012). Zionism, anti-Semitism, and colonialism. Al-Jazeera (2012).https://www.aljazeera.com/indepth/opinion/2012/12/2012122491229 12381.html (Retrieved on 25 March 2019).

McClintock, Anne. (1995). Imperial Leather: Race, Gender, and Sexuality in the Colonial Contest. New York: Routledge.

Moscrop, John James. (2000). Measuring Jerusalem: The Palestine Exploration Fund and British Interests in the Holy Land. London: Leicester University Press.

Nicol, Bran. (2011). 'Detective fiction and "the original crime": Baurdrillard, Calle, Poe'. Cultural Politics, 7 (3): 445-464.

Obenzinger, Hilton. (1999). American Palestine: Melville, Twain, and the Holy Land Mania. Princeton, N. J.: Princeton University Press.

Poe, Edgar Allan. (1966). Complete Stories and Poems of Edgar Allan Poe. Garden City, N.Y.: Doubleday. 
Pratt, Mary Louise. (2008). Imperial Eyes: Travel Writing and Transculturation. London: Routledge.

Rachman, Stephen. (2010). 'Poe and the origins of detective fiction'. In Catherine Ross Nickerson (ed.), The Cambridge Companion to American Crime Fiction, 17-28. New York: Cambridge UP.

Rose, Jacqueline. (1996). States of Fantasy. Oxford: Clarendon Press.

Said, Edward. (1978). Orientalism. New York: Pantheon Books.

Salaita, Steven. (2006). The Holy Land in Transit: Colonialism and the Quest for Canaan. Syracuse: Syracuse University Press.

Scaggs, John. (2005). Crime Fiction. London: Routledge.

Segal, Eyal. (2010). 'Closure in detective fiction'. Poetics Today, 31 (2): 153215.

Sherman, A. J. (1998). Mandate Days: British Lives in Palestine, 1918-1948. New York: Thames and Hudson.

Soetendorp, David. (1971). 'My song, my sorrow, my passion: "Jacob Israel de Haan" 1881-1924'. European Judaism: A Journal for the New Europe, 5 (2): 8-10.

Spanos, William V.(1972). 'The detective and the boundary: Some notes on the postmodern literary imagination'. boundary 2, 1(1): 147-168. Reprinted in Daniel T. O'Hara, Donald E. Pease, and Michelle Martin (eds.),Humanist Criticism and the Secular Imperative: A Spanos Reader,31-50. Evanston, Illinois: Northwestern University Press, 2015.

Stahler, Axel.(2009). 'Metonymies of Jewish postcoloniality: The British Mandate for Palestine and Israel in contemporary British Jewish fiction'. Journal for the Study of British Cultures, 16 (1): 27-40.

Storrs, Ronald. (1937). The Memoirs of Sir Ronald Storrs. New York: G. P. Putnam's Sons.

Weese, Katherine. (2015). 'Detection, colonialism, postcolonialism: The sense of an ending in Julian Barnes's Arthur and George'. Journal of Narrative Theory, 45(2): 301-329.

Wilson, Jonathan. (2003). A Palestine Affair. New York: Pantheon Books. 